\title{
Correction to: An attempt to explain the neurological symptoms of Myalgic Encephalomyelitis/Chronic Fatigue Syndrome
}

Klaus J. Wirth ${ }^{1 *} \mathbb{D}$, Carmen Scheibenbogen $^{2^{*}}$ and Friedemann Paul ${ }^{3}$

\section{Correction to: Journal of Translational Medicine (2021) 19:471 https://doi.org/10.1186/s12967-021-03143-3}

Two errors were noticed after publication of the original article [1]:

1. Carmen Scheibenbogen should also be a corresponding author

2. 4 references and their citations were missing [2-5] in the Decreased cerebral blood flow (CBF) section.

The original article has been updated to correct these errors.

\footnotetext{
Author details

${ }^{1} \mathrm{KOSA}$ Pharma GmbH, Frankfurt am Main, Germany. ${ }^{2}$ Institute of Medical Immunology, Charité - Universitätsmedizin Berlin, Corporate Member of Freie Universität Berlin, Humboldt-Universität Zu Berlin, and Berlin Institute of Health, Berlin, Germany. ${ }^{3}$ Experimental and Clinical Research Center, Max Delbrück Center for Molecular Medicine and Charité Universitätsmedizin Berlin, Berlin, Germany.
}

Published online: 11 January 2022
References

1. Wirth KJ, Scheibenbogen C, Paul F. An attempt to explain the neurological symptoms of Myalgic Encephalomyelitis/Chronic Fatigue Syndrome. J Transl Med. 2021:19:471. https://doi.org/10.1186/s12967-021-03143-3.

2. Campen C, Rowe PC, Visser FC. Reductions in cerebral blood flow can be provoked by sitting in severe Myalgic Encephalomyelitis/Chronic Fatigue Syndrome patients. Healthcare (Basel). 2020. https://doi.org/10.3390/ healthcare8040394.

3. van Campen C, Rowe PC, Visser FC. Cerebral blood flow is reduced in severe Myalgic Encephalomyelitis/Chronic Fatigue Syndrome patients during mild orthostatic stress testing: an exploratory study at 20 degrees of head-up tilt testing. Healthcare (Basel). 2020. https://doi.org/10.3390/ healthcare8020169.

4. van Campen C, Verheugt FWA, Rowe PC, Visser FC. Cerebral blood flow is reduced in ME/CFS during head-up tilt testing even in the absence of hypotension or tachycardia: a quantitative, controlled study using Doppler echography. Clin Neurophysiol Pract. 2020;5:50-8. https://doi.org/10. 1016/j.cnp.2020.01.003.

5. van Campen CMC, Rowe PC, Visser FC. Cerebral blood flow remains reduced after tilt testing in Myalgic Encephalomyelitis/Chronic Fatigue Syndrome patients. Clin Neurophysiol Pract. 2021;6:245-55. https://doi. org/10.1016/j.cnp.2021.09.001.

\section{Publisher's Note}

Springer Nature remains neutral with regard to jurisdictional claims in published maps and institutional affiliations.

The original article can be found online at https://doi.org/10.1186/s12967021-03143-3.

\footnotetext{
${ }^{*}$ Correspondence: Wirth-Kriftel@t-online.de;

Carmen.Scheibenbogen@charite.de

${ }^{1}$ KOSA Pharma GmbH, Frankfurt am Main, Germany

${ }^{2}$ Institute of Medical Immunology, Charité - Universitätsmedizin Berlin Corporate Member of Freie Universität Berlin, Humboldt-Universität Zu Berlin, and Berlin Institute of Health, Berlin, Germany

Full list of author information is available at the end of the article
}

(c) The Author(s) 2021. Open Access This article is licensed under a Creative Commons Attribution 4.0 International License, which permits use, sharing, adaptation, distribution and reproduction in any medium or format, as long as you give appropriate credit to the original author(s) and the source, provide a link to the Creative Commons licence, and indicate if changes were made. The images or other third party material in this article are included in the article's Creative Commons licence, unless indicated otherwise in a credit line to the material. If material is not included in the article's Creative Commons licence and your intended use is not permitted by statutory regulation or exceeds the permitted use, you will need to obtain permission directly from the copyright holder. To view a copy of this licence, visit http://creativecommons.org/licenses/by/4.0/. The Creative Commons Public Domain Dedication waiver (http://creativeco mmons.org/publicdomain/zero/1.0/) applies to the data made available in this article, unless otherwise stated in a credit line to the data. 